Dranus Valentyn, Ph.D. in Economics, Associate Professor Petro Mohyla Black Sea National University, Mykolaiv, Ukraine

ORCID ID: 0000-0001-5617-6740

e-mail:drval8@ukr.net

Dranus Liubov, Ph.D. in Economics, Associate Professor Petro Mohyla Black Sea National University, Mykolaiv, Ukraine

ORCID ID: 0000-0002-6427-1315

e-mail: lyuba_melnichuk@ukr.net

\title{
Current Situation and Prospects of Agricultural Insurance Development in Ukraine
}

Introduction. Insurance is an integral part of modern business processes and the most important way to minimize economic losses due to adverse events and phenomena. By facilitating the redistribution of risks between economic agents and the accumulation of losses through insurance, it (insurance) allows to increase the efficiency of the economy as a whole and its individual elements. The role of insurance is particularly important in the agricultural sector, as it is mostly prone to natural and climatic risks. As a financial institute of insurance for the domestic economy it is at a rather low level in comparison with foreign experience: a narrow range of insurance products, primitive technologies, underdeveloped infrastructure, does not fully take into account the specificity of the agricultural sector.

In many ways, the development of insurance agribusiness is constrained by insufficiently developed theoretical and methodological issues and, consequently, by the poor validity of its priority areas. Noting that the problems of formation and development of the market of insurance services in the agrarian sphere are quite deeply theoretically and practically investigated, it should be acknowledged that in the present conditions many issues related to the specifics of the development of insurance market institutions require further research, including: development of methodological approaches to determine the main directions of development of agricultural insurance; substantiation of the concept of insurance development in agriculture of Ukraine.

Purpose. Theoretical substantiation of priority directions of the agricultural insurance system development and the formation of practical recommendations on the basis for their implementation are observed.

Results. The question of the current state of agricultural insurance in Ukraine, which is developing, mainly in quantitative terms due to the expansion of insured areas, nomenclature of insurance objects, is considered. Improving the quality of industrial risk insurance, which is reflected in the effective use of funds for these purposes, the application of reinsurance, differentiated insurance rates, the implementation of insurance payments in the presence of real damage and in the amount stipulated by insurance conditions, remain unresolved. The reasons, why agricultural insurance is not required is that the current agricultural insurance system has a number of significant disadvantages. The biggest problems remain of financial and economic nature, which include, first of all, the difficult financial position of agricultural producers, high loss of agricultural insurance and insufficient development of the reinsurance market. The low solvency of farmers determines the need for state support, since the need for borrowed funds to pay insurance premiums, even in the presence of subsidies, is maintained when underinsured, and under the insurance against total loss of crops, and in the case of combined tariffs.

Another defining reason why agro - insurance has not yet become an effective financial protection tool for the industry is the lack of awareness among agricultural producers about its capabilities. Because of this, the level of insurance coverage is often misjudged at the stage of concluding an insurance contract. The current state of agricultural producers' insurance market, the price of current insurance tariffs and conditions of using insurance products, the size of the franchise, insurance coverage and insurance indemnity in case of unfavorable conditions for salt are analyzed as well as the differences in periods of crops acceptance for insurance. The differences between index and mutual insurance from traditional ones, the characteristics and methods of index calculation, the possibility of combining manufacturers to cover the risks that fall out of index insurance coverage are established.

The level of application of risk management instruments, reasons for refusal of insurance products, opportunities and conditions for improvement of the state on the agro insurance market, application of reinsurance operations with insured acreage of agricultural crops, combination of different types of agricultural insurance, advantages and disadvantages of alternative insurance instruments, possibilities for insurance options, are determined as well as their widespread use in agricultural insurance.

Conclusions. The necessity of using innovative insurance instruments in the financial activity of agricultural producers, the necessity of the state policy improvement in the field of agricultural insurance and creation of the necessary conditions for the development of the agrarian insurance market that could satisfy the needs of all participants of the insurance market were proved.

Keywords: Agricultural Insurance; Mutual Insurance; Index Insurance; Reinsurance; Yield Index; Weather Index.

удК 338:368.5

Дранус В. В., кандидат економічних наук, доцент кафедри економіки та підприємництва, Чорноморський національний університет ім. Петра Могили, м. Миколаїв, Україна 
Дранус Л.С., кандидат економічних наук, доцент кафедри менеджменту, Чорноморський національний університет ім. Петра Могили, м. Миколаїв, Україна

\section{Сучасний стан та перспективи розвитку інструментів сільськогосподарського страхування в Україні}

Страхування є невіддільною складовою сучасних бізнес-процесів та найважливішим способом мінімізації економічних втрат внаслідок настання несприятливих явищ і подій. Роль страхування особливо важлива в аграрній сфері, оскільки вона найбільш схильна до впливу природно-кліматичних ризиків. Як фінансовий інститут страхування для вітчизняної економіки знаходиться на досить низькому рівні: вузьке коло страхових продуктів, примітивні технології, нерозвинена інфраструктура.

Багато в чому розвиток страхового агробізнесу стримується недостатньо розробленими теоретичними та методичними питаннями й слабкою обгрунтованістю його пріоритетних напрямів. Проблеми формування і розвитку ринку страхових послуг в аграрній сфері теоретично і практично досліджені, але в сучасних умовах існує багато питань, пов'язаних зі специфікою розвитку інститутів страхового ринку, які потребують подальшого дослідження, а саме: розроблення методологічних підходів до визначення основних напрямів розвитку агрострахування; обгрунтування концепції розвитку страхування в сільському господарстві Украӥни.

Метою дослідження $\epsilon$ теоретичне обгрунтування пріоритетних напрямів розвитку системи сільськогосподарського страхування та формування на цій основі практичних рекомендацій щодо їх реалізації.

У результаті дослідження розглянуто питання сучасного стану сільськогосподарського страхування в Україні, що розвивається. Підвищення якості страхування виробничих ризиків, що полягає в ефективному використанні коштів на дані цілі, застосування перестрахування, страхових тарифів, що диференціюються, залишаються невирішеними. Чинна система сільськогосподарського страхування має ряд істотних недоліків. Найбільшими залишаються проблеми фінансово-економічного характеру, до яких насамперед належать важке фінансове становище сільськогосподарських виробників, висока збитковість сільськогосподарського страхування, недостатній розвиток перестрахувального ринку. Низька платоспроможність сільськогосподарських виробників визначає необхідність державної підтримки, оскільки потреба в позикових коштах для оплати страхового внеску зберігається $і$ при страхуванні від недоотримання врожаю, і при страхуванні від повної загибелі посівів, $і$ в разі застосування комбінованого тарифу.

Проаналізовано сучасний стан ринку страхування сільськогосподарських товаровиробників, ціну чинних страхових тарифів та умови використання страхових продуктів, розміри франшизи, страхового покриття та страхового відшкодування у випадках настання несприятливих умов для сільськогосподарських товаровиробників, відмінності в періодах прийняття посівів на страхування. Встановлено відмінності індексного та взаємного страхування від традиційного, можливості об'єднання виробників для покриття ризиків, які випадають з покриття індексним страхуванням. Визначено рівень застосування інструментів управління ризиками, причини відмови від страхових продуктів, можливості та умови покращення стану на ринку аграрного страхування, застосування перестрахових операцій із застрахованими посівними площами сільськогосподарських культур, поєднання різних видів сільськогосподарського страхування, переваги та недоліки альтернативних інструментів страхування, можливості та перешкоди для їх широкого застосування в сільськогосподарському страхуванні.

Доведено необхідність використання інноваційних інструментів страхування у фінансовій діяльності сільськогосподарських товаровиробників, необхідність покращення державної політики у сфері сільськогосподарського страхування та створення необхідних умов для розвитку ринку аграрного страхування, що змогли б задовольнити потреби всіх учасників страхового ринку.

Ключові слова: страхування в сільськогосподарському виробнищтві; взаємне страхування; індексне страхування; перестрахування; індекс врожайності; індекс погоди.

Formulation of the problem. According to the State Statistics Service, the real gross domestic product of Ukraine increased by $3.3 \%$ in 2018 after its increase by $2.5 \%$ in 2017 and by $2.4 \%$ in 2016, with a nominal GDP of UAH 3 trillion 558,7 billion The share of agricultural products amounted to UAH 360757 million or $10.1 \%$ [1]. However, the quantitative indicators of the agricultural sector are in conflict with the qualitative indicators of insurance activity. Agricultural land covers 42 million hectares, of which only 974 thousand hectares were insured in 2018, which is about 9\%. Existing insurance products do not meet the needs of agricultural producers, so the agricultural insurance market in Ukraine requires the use of innovative approaches to the policy of formation and sale of insurance services, which in their quantitative and qualitative parameters satisfy the financial and economic interests of agricultural producers.
Analysis of recent research and publications. The problems of agro-insurance, organization and development are the attention focus of many domestic and foreign economists. In particular, Yu.Aleskerova, V.Bazilevich, N.Vnukov, O.Gamankova, O.Gudz, D.Dema, S.Navrotsky, S.Osadets and others devoted their works to the problems of agricultural production insurance. However, the issue of using the latest agricultural insurance practices and techniques in today's economic environment is increasingly demanding. Therefore, analyzing and comparing the different instruments and methods of implementing insurance in agriculture and identifying the most effective is relevant and requires further investigation. Highly appreciating the scientific achievements of these authors, it is necessary to recognize the insufficient attention of scientists to the development of innovative insurance products, adequate to the requirements of the modern agrarian market. 
Formulation of research goals. The purpose of the study is to analyze the current state of the agricultural insurance market and formalize the financial instruments of mutual and index insurance of agricultural activity as a harmonization form of interests at the subjects of the agricultural market.

Outline of the main research material. Insurance in agricultural production is one of the risk management tools and minimization of losses in case of crop losses and in case of extreme weather conditions. The spread of insurance stabilizes the agricultural sector of the economy and reduces the burden on the state budget in the event of massive crop losses among agricultural producers.

There have been several attempts to implement largescale agri-insurance in Ukraine. In 2005-2007, a state subsidy program was implemented, but it failed due to the unprofessional nature of insurance companies in developing specific types of products for agricultural markets and working with crop loss estimators. Another reason for the failure of the agricultural insurance program was the complexity of the procedure for obtaining a state subsidy and the need to pay for it. In 2012, the Law "On Specific Features of State-Supported Agricultural Products" was adopted. Agrarian insurance pool was also created from several insurance companies, which were developed as a unified line of agricultural insurance types. The written above measures, as well as models of agricultural producers insurance with the comprehensive participation of insurance companies and the state, offered by S.Navrotsky [2, p.90], Yu.Aleskerova [3, p.100], V.Dranus [4, p.20-21], unfortunately did not find their reflection in the practical activity or did not fulfill the functions assigned to them.

The state should develop standard types of agricultural insurance, as well as to carry out information campaigns on subsidies and engage in certification of appraisers. State control will allow insurance companies to enter the market more freely. We consider such control better than the monopolization of the market by several large insurance companies.

Opinions differ on insurance products available to farmers. T.Sinitsyna concludes on a limited range of insurance products for agrarians, since the insurance of agricultural production may be subject to insurance: costs incurred by the enterprise for their production; future expected harvest; future expected revenue from crop production. In Ukraine, agricultural insurance covers only the first two points [5, p. 49]. Leading expert in the field of agricultural insurance IFC project "Development of agricultural sector financing in Europe and Central Asia" A.Zaripov identifies several main types of agricultural insurance:

- production cost insurance: relatively cheap but without compensation for potential income and potential yield;

- winter crop insurance: provides compensation in the event of damage or loss of crops in specific terms, but there are difficulties with inspection of crops and possible delay in payments;

- crop insurance: the price for the future crop is agreed, it is necessary to provide the insurance company with statistics on the farm for 5 years and a technological map. Production insures potential yields on detailed risks, but the loss assessment system is very complex;

- income insurance: harvest price, price indicator, price fixing date, list of risks and method of their evaluation are agreed. This type is practically not used in Ukraine because of its high cost and complexity;

- insurance against one or more types of risk;

- index insurance: insurance is based not on the statistics of the economy, but on the average indicator by region. There is no need to evaluate crops on the ground, but there is a risk that the farm performance differs from the regional average and then the insurance will not provide sufficient financial protection [6].

Director of Corporate Insurance of ASKA Insurance Company E.Shustur states that today the market of agricultural insurance combines three key areas:

- crop insurance and future crops. Exactly this type of insurance appears in the report about the regulator of the insurance market, and in the analytics of the Ministry of Agrarian Policy, it can receive enough objective data on net contracts, insurance payments, etc .;

- insurance of agricultural machinery. Agrarians often resort to this type of insurance protection, but there is no reliable data on the volume of the market - agricultural machinery is protected in the same way as cars by the CASCO program, which is why no individual statistics are kept;

- cargo insurance - from the agricultural producer to the place of storage or processing. This type of insurance protection is becoming more and more relevant for agrarian companies, but there are no separate indicators - statistics on transport insurance by industry are not maintained [7]. Traditional crop insurance, which provides compensation to an individual entity, is mostly associated with significant administrative costs (enterprise monitoring, loss assessment, standardization of contracts, etc.). According to Professor O. Gudz, traditional insurance also requires considerable investment for actuarial calculations, as well as for monitoring yields in farms to prevent large losses [8, p. 75]. In addition, classic crop insurance is associated with significant natural, climatic, industrial, financial, commercial and politicallegal risks that may occur at the same time and therefore require additional reinsurance costs.

In Ukraine, only $5 \%$ of farmers use risk management tools, one of the reasons being the high cost and low quality of insurance products. The main purpose of agricultural risk insurance is partial or full compensation to the policyholder for the loss of the crop, which is possible due to the influence of various adverse factors. The sum insured for crop insurance is determined by the following formula: the average yield over the last 3-5 years in a given farm or district is multiplied by the area of the sown field that will be insured and multiplied by the value 
of the unit of harvest. The sum insured when insuring the costs of planting or growing crops may include: the cost of the seed, the cost of mineral fertilizers, the salary, the cost of plant protection products, fuel and lubricants, etc.

It should also be noted the differences in the periods of acceptance for winter and spring crops:

- winter insurance is accepted: 1) for the wintering period (from early November to mid-December, 2) the inspection is carried out after the emergence of sprouts;

- spring crops are accepted for insurance from the beginning of May and the inspection is carried out after the emergence of the seedlings.

The size of the franchise, depending on the risks and under the agreement of the parties, can range from $20 \%$ to $50 \%$ of the sum insured by the field (from $10 \%$ when insuring perennial crops). The insurance rate can range from $2.0 \%$ to $7.0 \%$ or more of the sum insured.

In the case of crop insurance, the loss of the policyholder from the loss (non-receipt) of the crop as a result of total or partial loss, loss or damage of the crop due to the occurrence of an insured event is a loss. A crop failure is defined as the difference between the insurance value of the crop specified in the insurance contract and the value actually obtained after the occurrence of the crop insurance event. The Insurer checks the reports of the crop loss or crop damage on the materials of the Hydrometeorological Service and other organizations that monitor the natural phenomena, and the circumstances of the insured event, including by inspection at the scene.

If the crop failure (crop group) is caused not by insurance reasons, but by violations of agrotechnical rules for soil cultivation, lowering the rate of mineral fertilizers application into the soil, violations of the seedings rates and other reasons, then insurance compensation is not paid [9].

The cost of insurance costs depends on many factors. Cost insurance saves the manufacturer money on insurance, since the sum insured is calculated from the amount of costs (including interest on credit) and does not take into account the cost of sales. Cost and crop insurance are usually the same, and the insurer can save money by choosing cost insurance or through franchise or coverage levels.

It is proposed to conclude non-deductible insurance contracts as coated products are clearer and simpler. By entering into a covered insurance contract, the company knows exactly at what level of crop losses the insurer is liable, and what amount of compensation can be obtained. In addition, the tariff rate (tariff) in coverage products more accurately reflects the real cost of the insurance service [10].

It should be noted that products with large franchises (40-50\%) and / or low coverage (50-60\%) are cheaper, but they only offset a small fraction of the manufacturer's costs or revenue. Such products may be convenient for securing collateral when getting a loan, but the manufacturer must remember that he does not receive reliable insurance protection, so when a risk event occurs, he will have to pay off his debt to creditors more independently and rely on insurance that can only partially be recovered.

Attempts to develop insurance in agriculture have traditionally been based on the objectivity of risk assessment and its systematic nature: when the insurer lacks confidence in the will absence of the interested parties and in the estimation of the losses amount, as well as a real opportunity to monitor and control it. That is, the risk may be lost by the criteria of chance occurrence, which underlies the very basis of insurance. The main reason for the crop losses is weather conditions. According to IFC, in $58 \%$ of cases, the cause of the crop losses is weather, $17 \%$ is disease, $15 \%$ is weed and $10 \%$ is pest [11].

The high cost of insurance products, combined with the limited financial resources of agricultural producers themselves, reduces the spread of agricultural insurance. According to the statistics on crop insurance for 2018 in Ukraine, 1205 such contracts were recorded worth about 209 million UAH, about 9\% of all acreage was insured, or 974 thousand hectares [1]. In order to increase the level of insurance coverage of producers with state-backed agricultural insurance, we consider it is advisable to use insurance instruments that provide for the possibility of pooling risks within Mutual Insurance Companies and the introduction of index insurance instruments.

The basis of index insurance is a certain defined parameter (index). Hence, from it is its name «index insurance». There are many varieties of index insurance products. In particular, weather and crop yields can be distinguished when taking into account, for example, the average yield of an insured crop within a district, region or country as a whole. Indices are calculated based on statistics collected over a defined territory over a long period. Index insurance provides for the insurer's right to compensation if the yield of the insured culture falls below the guaranteed level. For example, some insurance companies may set it at $70 \%$ of the crop's long-term yield in a specific area, sometimes smaller. Unlike traditional insurance, the index does not require a mandatory preinsurance inspection of the crops and an assessment of the damage suffered by the farm.

According to M. Nazarenko, index insurance provides transparency and eliminates subjective approaches in the assessment process. Insurance payments in the event of insured events are made on the basis of independent publicly available meteorological data [12].

Index insurance also greatly simplifies valuation and payment processes. This is primarily due to the fact that insurers do not need to go to the fields to assess losses. The payout rate depends on the selected parameter (index).

Insurance companies in Ukraine have started to work with index agricultural products since 2003. While index insurance has not become popular with manufacturers, interest in these products is expected to increase as farms 
become accustomed to using insurance as a way to protect their crops and income.

Distinctive characteristics of index products should be noted the objectivity of the process of damage assessment and the absence of a franchise. There are two types of index products available in Ukraine - the yield index and the weather index.

Currently, the yield index is offered only for field crops. This product allows you to insure crops at the average yield (each crop) in the administrative area. The yield index should be of interest to the medium-sized enterprise, whose yield in the farm usually coincides with the average yield in the area. Adjustment of losses is carried out not according to the results of the harvest in the economy, but according to the data of the state statistics agencies. The index crop insurance contract specifies the level of coverage, the tariff rate, and a scale or payment table for each unit of underperformed crop should be present to a catastrophic level when the insured farm receives the full payment.

According to the yield index agreement, the settlement of losses is carried out almost automatically, after receiving the statistics, and the parties practically do not participate in determining the losses or the percentage of loss of a crop from a particular risk event. The disadvantage of insurance on the yield index is the term of determining the index, which depends on the publication of data by the State Statistics Service and may delay the payment of compensation up to half a year after the harvest. Another disadvantage of this insurance product is that the company may have losses but does not receive insurance compensation if the average yield in the area is within the normal range. Yield index is cheaper than comprehensive insurance. The tariff rate mainly depends on the yield fluctuations of a particular crop in the area over the last $10-30$ years. Rates on the yield index are in the range of $3-10 \%$, depending on the level of coverage $(50 \%, 60 \%, 70 \%)$ and the riskiness of the region.

Weather index products are under implementation in Ukraine. This is a fairly new type of insurance products that allow you to relatively easily determine the damage caused by adverse weather events when growing different crops. The weather index is calculated based on the weather data for the last 20-30 years for each weather station. Understanding the dependence of plant development and yield formation on the effects of various weather factors helps to establish the relationship between crop losses and deviations of weather parameters from the average long-term values fairly accurately.

The weather index can be calculated for different crops and different periods for crop insurance. CredoClassic Insurance Company offered grain producers in Kherson Region three insurance products for drought crop insurance. The rate of insurance of wheat and barley against drought by the index of insufficient rainfall was $8 \%$ for the eastern part of Kherson region. Insurers could receive compensation (insurance payment) in the event that the amount of rainfall during the insurance period would be less than $50 \mathrm{~mm}$ (average annual amount -80 $\mathrm{mm}$ ). The entire sum insured would be paid if the amount of rainfall was less than $30 \mathrm{~mm}$ [13].

The disadvantage of weather index products is the "risk of the basics", when an enterprise may not receive compensation if the weather index is recorded within normal limits, but the enterprise will receive losses (e.g. frost, drought).

Such problems may arise for businesses whose fields are far from the weather station, but insurance companies can offer options for solving similar problems (setting up an automatic weather station in the fields of the enterprise, calculating the index for several stations, etc.). Damage adjustment is carried out according to the weather station of the Ukrainian Hydrometeorological Center. Unfortunately, the resource of the Ukrainian hydrometer is limited. It operates only 164 weather stations. Often, they are at a great distance from individual farmland, so it is not easy to monitor the situation that arises on or near them [14].

Index insurance is devoid many disadvantages of conventional, now accepted risk insurance in the agricultural sector. The asymmetry of information disappears, which becomes equally accessible to both the insurer and the insured as it is taken from open and accessible sources. It is this quality that attracts reinsurers and allows them to easily track risks. Thus, part of the loss is not covered by index insurance can be compared to a deductible of $50 \%$, which is taken in the same "Agrarian Insurance Pool". The cost of index insurance for the policyholder can be several times cheaper than traditional insurance. The cost of risky commercial insurance is about $5 \%$ of the sum insured, index - of $3 \%$ and below. Index insurance does not require complex highly qualified underwriting and it is much easier and less expensive to organize and maintain. In this case, the insurance costs are also cheaper and the administrative costs of monitoring and assessing losses are minimized. The occurrence of an insured event is recorded on the basis of an independent and publicly available source of information.

Payment of insurance indemnity on weather index insurance products is made as soon as possible (up to 45 days after the expiry of the insurance coverage), so the company can plan its actions and financial decisions as soon as the weather station records the onset of the insured event, rather than waiting for the end of the procedure for loss assessment and the decision of the insurance company, which can often last up to 6 months.

Successful functioning of State Statistics Service in agricultural insurance is connected with a long history of their existence, which allows to accumulate the necessary resources at the expense of working with other noncatastrophic risks and establishing conditions of activity by the members of the society. However, given that members of the Committee are most often concentrated in a particular territory, a regional emergency is likely to jeopardize the financial sustainability of a company, as its 
financial resources are limited by the ability of members to make additional contributions in the absence of a Mutual Insurance Companies. In order to solve the above problem, the State Statistics Service may act as an aggregator of risks for their further transfer to the reinsurer.

Note the possibility of using mutual insurance in combination with the index to create a workable model of insurance relations in the agricultural sector. Mutual Insurance Companies could bring together manufacturers to cover the risks that fall out of index coverage. That is, that part of the risk that could be a burden on the policyholder could be covered by mutual insurance. This is both a cheapening of the case, the availability of qualified agricultural specialists, and the internal selection of members of the Mutual Insurance Companies. As a result, this will also reduce the cost of insurance.

But the likelihood remains that the element can still bring significant damage. Mutual Insurance Companies will be able to place a critical part of the risk in reinsurance on the local or foreign market of ordinary commercial reinsurance. State support for crop insurance can be provided in the segment of reinsurance of agricultural index risks abroad. After all, according to World Trade Organization rules, in which Ukraine is a member, direct support (subsidies) to agricultural enterprises is forbidden, but reimbursement of insurance part premiums is allowed.

Analysis of existing insurance products for agricultural producers allows to change or modify insurance conditions for them. This approach can help to really use both state budget funds, if the state provides financial support, and the funds directly to the agricultural companies that pay the insurance cost. There is no effective insurance system for the agricultural sector in Ukraine yet, but we hope that we will have soon a consistently developed insurance system, conducting a professional evaluation of possible insurance products and forms of state support, the state and the insurance sector in Ukraine will be able to create such a system of agricultural risk management that will help solve various and complex problems in the agricultural sector of production.

Conclusions and prospects for further research. The results of the analysis of the agricultural insurance market indicate a low level of use of insurance protection, since in 2018 only $9 \%$ of the acreage was insured, which indicates high potential. To improve the situation, existing agricultural insurance instruments must be used, and traditional crop insurance products require sophisticated contract management solutions (underwriting, monitoring, loss assessment and information collection) and are quite costly to farmers. It is advisable for agricultural enterprises to use index and mutual insurance instruments, which will insure crop yields against adverse climatic phenomena, taking into account the influence on their natural properties. This approach will provide the insurance service that will meet the needs of the policyholder best of all.

Further studies on the introduction of index insurance in Ukraine, the strengthening of mutual insurance role, the effective interaction of all participants of the insurance market in agricultural production are relevant.

\section{References:}

1. State Statistics Service of Ukraine. Official web-site. Retrieved from http://www.ukrstat.gov.ua [in Ukr.]

2. Navrotskyi, S. A. \& Paliukh, O. M. (2015). Comprehensive assessment of the effectiveness of development of the agricultural sector of Ukraine, taking into account the impact of public funding. Ekonomichnyi chasopys-XXI, 3-4(1), 88-92. [in Ukr.].

3. Aleskerova, Yu. V. (2014). Improving state support for agricultural insurance. Oblik i finansy, 4 (66), 95-102. [in Ukrainian].

4. Dranus, V. V. (2016). Organizational and economic model of management of industrial risk insurance with state support in agriculture. Naukovi pratsi. Ekonomika, 275(263), 18-22. [in Ukrainian].

5. Sinitsyna, T. V. (2011). Crop insurance products: a comparative haracteristic. Ahrosvit, 9, 48-52 [in Ukrainian].

6. Zaripov, A. Agricultural insurance in Ukraine: problems and solutions. Retrieved from https://aggeek.net/rublog/agrostrahovanie-v-ukraine-problemy-i-resheniya [in Russ.].

7. Shustur, O. Minimizing operational risks: insurance for farmers. Retrieved from https://landlord.ua/news/minimizatsiiaoperatsiinykh-ryzykiv-strakhuvannia-dlia-ahrariiv/ [in Ukrainian].

8. Gudz, O. Ye. (2006). Agro-risk insurance and directions of development of agricultural insurance in Ukraine. Ekonomika APK, 8, 72-76. [in Ukrainian].

9. Agricultural risk insurance - crop production. Retrieved from http://consoris.com.ua/rast/ [in Ukrainian].

10. Cost of cost insurance and basic conditions that affect the price of agricultural insurance. Retrieved from http://agroinsurance.com/tariff/87

11. International Finance Corporation: IFC. Official web-site. Retrieved from https://www.ifc.org [in Ukrainian].

12. Nazarenko, M. Indeksne strakhuvannia dlia ahrariiv: sut ta perevahy. Retrieved from https://propozitsiya.com/ua/indeksnestrahuvannya-dlya-agrariyiv-sut-ta-perevagy [in Ukrainian].

13. Index Insurance for Farmers: The Essence and Benefits. Retrieved from http://agro-insurance.com/product/97 [in Russ.].

14. Ukrainian Hydrometeorological Center. Official web-site. Retrieved from https://meteo.gov.ua [in Ukrainian]. 